$11-9-2011$

\title{
Structural Pluralism and the Community Context: How and When Does the Environment Matter?
}

\author{
Leo Wayne Jeffres \\ Cleveland State University, I.jeffres@csuohio.edu \\ Edward Horowitz \\ Cleveland State University, e.horowitz1@csuohio.edu \\ Cheryl Campanella Bracken \\ Cleveland State University, c.bracken@csuohio.edu
}

Guowei Jian

Cleveland State University, g.jian@csuohio.edu

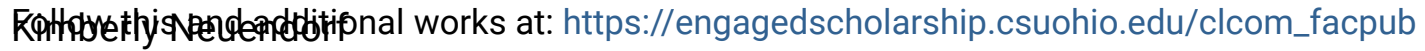

veland State University K.NEUENDORF@csuohio.edy the Social Influence and Political

Communication Commons

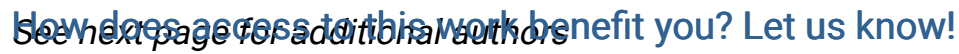

\section{Publisher's Statement}

This is an Author's Accepted Manuscript of an article published in Mass Communication and Society 11-09-2011, available online: http://www.tandfonline.com/10.1080/

15205436.2010.515371

\section{Recommended Citation}

Jeffres, L., Horowitz, E., Bracken, C. C., Jian, G., Neuendorf, K. A., \& Yoon, S. (2011). Structural pluralism and the community context: How and when does the environment matter? Mass Communication and Society, 14(6), 787-815. doi:10.1080/15205436.2010.515371

This Article is brought to you for free and open access by the School of Communication at EngagedScholarship@CSU. It has been accepted for inclusion in Communication Faculty Publications by an authorized administrator of EngagedScholarship@CSU. For more information, please contact library.es@csuohio.edu. 


\section{Authors}

Leo Wayne Jeffres, Edward Horowitz, Cheryl Campanella Bracken, Guowei Jian, Kimberly Neuendorf, and Sukki Yoon 


\title{
Structural Pluralism and the Community Context: How and When Does the Environment Matter?
}

\author{
Leo Jeffres, Edward Horowitz, Cheryl C. Bracken, \\ Guowei Jian, and Kimberly A. Neuendorf \\ School of Communication \\ Cleveland State University \\ Sukki Yoon \\ Department of Marketing \\ Bryant University
}

Leo W. Jeffres (Ph.D., University of Minnesota, 1976) is a Professor in the School of Communication at Cleveland State University. His research interests include neighborhoods and urban communication systems, communication technologies and media effects. Most recently he has focused on creation of the Urban Communication Audit and the concept of "communication capital" and its relationship to community involvement.

Edward Horowitz (Ph.D., University of Wisconsin, 2001) is an Associate Professor in the School of Communication at Cleveland State University. His research interests include political communication, civic engagement and socialization.

Cheryl C. Bracken (Ph.D., Temple University, 2000) is an Associate Professor in the School of Communication at Cleveland State University. Her research interests include psychological processing of media content, presence and communication technologies.

Guowei Jian (Ph.D., University of Colorado, 2003) is an Associate Professor in the School of Communication at Cleveland State University. His research interests include work and political participation, organizational change, information and communication technologies at work, and intercultural communication.

Kimberly A. Neuendorf (Ph.D., Michigan State University, 1982) is a Professor in the School of Communication at Cleveland State University. Her research interests include media and race/ethnicity, new media technologies, and affective correlates of media use.

Sukki Yoon (Ph.D., University of Illinois, 2005) is an Assistant Professor in the Department of Marketing at Bryant University. His research interests include advertising and communication.

Correspondence should be addressed to Leo Jeffres, School of Communication, Cleveland State University, MU253, Cleveland, OH 44115. E-mail: 1.jeffres@csuohio.edu 
Several long-standing theories intersect in discussing the impact of community characteristics and of the mass media. The structural pluralism model popularized by Tichenor and his colleagues says that social structure influences how mass media operate in communities because they respond to how power is distributed in the social system, whereas the linear model says that the increasing size of a community's population leads to more social differentiation and diversity and corresponding increases in subcultures with their own beliefs, customs, and behaviors. Recently, there has been a concern about how changes in society have led to a decline in organizational activity and the network of relationships and trust that constitute "social capital." This article examines the impact of population and diversity (using census data) on individuals' media use, interpersonal discussion and civic engagement (measured in a national survey), and the relationship among these variables. Analysis of a structural model provides evidence that the "linear hypothesis" can be combined with structural pluralism, with size - measured by populationimpacting diversity, which influences the relationships that people have with their community. Concurrently, social categories influence people's communication patterns and community relationships, and communication impacts civic engagement.

Several long-standing theories intersect in discussing the impact of community characteristics and of the mass media. First, the structural pluralism model popularized by Tichenor and his colleagues (Tichenor, Donohue, \& Olien, 1980) says that social structure influences how mass media operate in communities because they respond to how power is distributed in the social system. Second, the linear model from Toennies (1887/ 1957) and Wirth (1938) says that the increasing size of a community's population leads to more social differentiation and heterogeneity and corresponding increases in subcultures with their own beliefs, customs, and behaviors. More recently, there has been a concern about how changes in society have led to a decline in organizational activity and the network of relationships and trust that constitute "social capital" for community problem solving; both media and interpersonal communication have roles in this third stream of research.

The pluralistic model led to a body of work documenting how community characteristics, beginning with population size, affect media operations. Thus, the media reflect rather than affect the community. The linear hypothesis says that population growth leads to social differentiation, particularly in terms of occupation, and subsequent changes in people's behaviors; thus, there is direct impact on people. Although the sources of influence on social capital at the community level are less clear, declines in organizational membership have been attributed to suburbanization and a growing 
heterogeneity, both factors represented in the other theories, as well as changes in leisure time, particularly time spent watching television. ${ }^{1}$

These research traditions exist almost in isolation from each other while mass communication researchers study media effects that include the most recent focus on civic engagement, which is at the center of concerns about declines in social capital. In this article we examine these theories and proceed to raise research questions that integrate concepts appearing across all three. Then we utilize a national data set of respondents from communities of all sizes to answer these questions.

\section{THE PLURALISTIC MODEL}

The pluralistic model combined with systems theory popularized in mass communication research by the Minnesota team of Tichenor, Donohue, and Olien (Donohue, Olien, \& Tichenor, 1989; Olien, Donohue, \& Tichenor, 1978; Tichenor et al., 1980) is often cited but its origins seldom visited in recent years. Furthermore, because the model's home lies in sociology, few have attempted to empirically "dissect" what systems reflection means, or what useful interpretations should be examined. To recap, Tichenor and his colleagues, and subsequent followers within the field, take as their main focus of attention the issue of how mass media as institutions reflect the distribution of power in the larger society. In general, this has come to mean how media coverage or journalistic behaviors mirror community characteristics seen as operationalizing the notion of power (e.g., Berkowitz \& TerKeurst, 1999; Demers, 1994, 1996, 1998; Dunwoody \& Griffin, 1999; Hindman, 1996; Hindman \& Homstad, 2000; Hindman, Littlefield, Preston, \& Neumann, 1999; Viall, 1992). Research over the years has greatly expanded the range of topics covered by the media, as well as related practices such as public records access (Armstrong, 2008) and investigative reporting (Berkowitz, 2007).

These characteristics have included size of community, seen as the force behind increased heterogeneity of voices and power centers; greater occupational differentiation; and more organizations operating within the community (Tichenor et al., 1980). ${ }^{2}$ Others following Tichenor et al. have used similar measures to reflect greater dispersion or concentration of power

\footnotetext{
${ }^{1}$ These include scarcity of leisure time and expanding leisure options. Price (2002) noted that work-related time constraints lead to decreased participation in voluntary associations.

${ }^{2}$ The structural pluralism of communities in their model varies with their rank position on five factors: community population, number of businesses in the community, the number of volunteer groups, the number of churches, and the number of schools.
} 
while studying editors' perceptions, newspaper advertising expenditures, and content patterns reflecting emphasis on conflict news. ${ }^{3}$ The Minnesota team cites sociologist James S. Coleman (1961, 1964, 1980), whose writings focused on pluralistic arrangements and the concentration of power that affect the performance of social systems. Some of Coleman's work focused on educational systems and his concern that functional communities promoted better educational outcomes. Coleman also was concerned that social science research lead to the development of public policies, and he advocated a model of pluralistic policy research (Coleman, 1980).

There's a clear link between the older literature on structural pluralism and the more recently popular research on "social capital." Although structural pluralism says that size leads to the growth of different groups, which may be sources of power, social capital focuses on membership in formal groups, or organizations (see, e.g., Putnam, 1995), as a source of strength and involvement in communities; it is in such groups that personal relationships are forged and trust developed. Social networks are important elements in Coleman's theoretical work on development of trust and norms (Coleman, 1990) and social capital (Coleman, 1988). For Coleman (1988, p. S98), social refers to social structure features that facilitate action, including systems of trust and obligations, networks disseminating information, norms, centralized authority structures arising through transfers of control, and some aspects of social organization. ${ }^{4}$ This is consistent with the key

\footnotetext{
${ }^{3}$ These include the following measures of structural pluralism: citywide and countywide measures of population, education level, per capita income, number of nonfarm businesses and percentage of population in professional, managerial, or technical jobs (Demers, 1998, studying perceived critical content in newspapers through content analysis); city and county population, county per capita income, percentage of population not in agriculture (Hindman, 1996, studying emphasis on conflict in news hole using content analysis); community and county population, county per capita income, percentage of the population not employed in agriculture, and the distance of the community from a major metropolitan area (Olien, Tichenor, Donohue, Sandstrom, \& McLeod, 1990, studying editors' attitudes toward community planning via a survey); total resident population, number of civilians employed in nonagricultural jobs, and number of cities with a population of 100,000 or more (Demers, 1994, studying advertising expenditures of newpapers); average county population, average community population, per capita income, percentage labor and proprietor's income in manufacturing, and percent labor and proprietor's income in farming (Donahue, Olien, \& Tichenor, 1985, studying space devoted to crime, education, and politics as conflict reporting via content analysis); an index comprised of standardized measures of city and county population, number of residents with a bachelor's degree or higher education level, county per capita income, and percentage of the work force in nonagricultural, forestry, and fishery occupations (Hindman et al., 1999, studying editor's perceptions of ethnic minorities in power structure through survey).

${ }^{4}$ Coleman's own "structural" research included analyzes of friendship ties as elements of occupational community and diffusion analyses; his studies identified network subgroups, reference groups, and other network-related phenomena (Coleman, 1961).
} 
factors in the linear hypothesis, size, and social structure, which are seen as exerting their influence through social relationships.

\section{THE LINEAR HYPOTHESIS}

Coleman's work and the pluralistic model employed in mass communication by Tichenor and his colleagues follow the classic model in the tradition of Toennies (1887/1957) and Wirth (1938), which says that size and density are the primary factors influencing social behavior. What has been called the "linear hypothesis" begins with the notion of community size, which then affects social heterogeneity. Wirth argued that social heterogeneity increases with community size, but, as Wilson (1986) noted, he offered no rationale outside of occupational differentiation. In general, with size, sometimes labeled urbanism, comes an increasing variety of subcultures with their different sets of beliefs, values, norms, and customs. Wilson tested the notion that size leads to heterogeneity in values and attitudes, using a national data set comparing residents in the 12 largest standard metropolitan statistical areas with those in the 88 next largest standard metropolitan statistical areas and those living in smaller communities. All dependent variables examined varied with community size (e.g., political liberalism and tolerance for different social behaviors such as extramarital sex and homosexuality) except for equalization of wealth, which was highest in the largest areas and lowest in the medium-sized areas, and satisfaction, which was inversely related to community size; this pattern persisted with controls for such population characteristics as income, education, age, marital status, and race. Abrahamson and Carter (1986) analyzed other national data sets from 1947 to 1982 in a study of the effects of city size and region on indicators of tolerance, finding the effect of city size declined but the effect of region remained. None of these studies examined communication behaviors, the focus of this article. However, Pollock, Piccillo, Leopardi, Gratale, and Cabot (2005) linked community size to newspaper coverage of such stakeholder groups as Moslems; they noted the link between city size and plurality of viewpoints represented by the media in the work of Tichenor, Donohue, and Olien (1973).

In a research record spanning more than two decades of work, Tichenor and his colleagues carefully added community-level studies to a database that allowed for community comparisons in how media are influenced by the larger social-community system. Community size, thus, became a variable the influence of which could be studied along with measures of occupational differentiation and group membership. This record was largely built on data collected in small communities in the upper Midwest. Others 
following in this tradition have deviated now and then, but most have worked in similar contexts (e.g., Hindman, 1996). Add to this the suggestion by Harry (2001) that the social structure of small towns themselves is changing.

As a consequence, the operationalization of community size generally has been limited to a fairly narrow range of smaller communities in selected regions of the Midwest, and this comes at a time when $83 \%$ of Americans lived in metropolitan areas in 2003 (Mackun, 2005). Recently, a group of scholars has begun focusing on the urban context itself and the relationship between the community environment and communication. Those working in this direction also should be informed by the pluralistic perspective, and it opens up an opportunity for extending the line of research begun by the Minnesota trio in the 1970s.

The current efforts of urban communication scholars extend beyond media performance issues to questions about the relationship between environment and a broad range of communication variables and issues. But the urban communication group is also concerned with policies and the need for communication scholars to work with community planners and others whose decisions often are made without being informed by communication research. Thus, like Coleman, there is an interest in policy research.

\section{MERGING THE MODELS}

Here, we propose to merge these interests using a national dataset that includes community-level data across the broad range of American communities (from rural areas, to small towns, cities, and metropolitan areas) and individual-level data on a wide range of people's behaviors, including communication and social engagement. Technological advances in the past decade or so make possible a much more efficient matching of communitylevel characteristics with survey data than was possible earlier; the U.S. Census Bureau website provides access to a wide range of data by zip code, and Google street-level maps allow researchers to verify the environment being analyzed when zip codes are obtained for respondents.

The first variable employed by Tichenor and his colleagues was size of population, empirically related to heterogeneity on many dimensions. However, in a larger, national context, the environment in which people live can be viewed as a series of concentric circles moving farther outward from the immediate neighborhood to the larger community; to the county; and, for most people, the metropolitan area. Although some people live only in the first, second, or third circle, many are imbedded in multiple circles. 
Thus, there are many possibilities in how and what aspects of the environment impact people and their behaviors. People may live in the country, in a central city neighborhood or suburb of a metropolitan area, or in a small or large nonmetropolitan city. Add to this the fact that these contexts exist in a state or region where some cultural patterns may be more common; for example, in one national study, regional influences on norms persisted with social categories controlled (Abrahamson \& Carter, 1986). Each of these contexts can affect people's communication patterns and their opportunities for civic engagement, the target of much recent research (Scheufele, Nisbet, Broussard, \& Nisbet, 2004). ${ }^{5}$ Thus, it is an empirical question whether people are affected by any or all contexts. For example, a suburbanite may live in a homogeneous suburb of a large - and, thus, diverse - metropolitan area; yet if the individual restricts his behaviors and puts limits on incoming messages, the larger environment may be irrelevant.

This approach is consistent with a trend in the mass communication literature examining the impact of community and environment. Pollock's (2007) recent articulation of a community structure approach also looks at a variety of ways that key characteristics of communities are related to content coverage of newspapers, including, for example, the size of various stakeholders and groups of privilege or vulnerability. Armstrong (2008) suggested broadening the concept of community pluralism to examine leadership diversity.

Motivated by these diverse studies, we query the role of community size in several regards:

RQ1: Which of the indicators of community size are most strongly related to social differentiation at the neighborhood level? (This is a test of the assumption that population and occupational differentiation are

\footnotetext{
${ }^{5} \mathrm{~A}$ good example of this literature is found in Scheufele, Nisbet, Broussard, and Nisbet (2004), who looked at social settings where citizens discuss politics and its impact on political activity. They measured political activity via seven items tapping voting, attending meetings, contacting public officials, circulating petitions, working for campaigns, raising funds, and writing letters to the editor. They integrated into a single model predicting political participation not only interpersonal discussion networks (across three contexts-work, volunteering, and church) but also network heterogeneity and attention to both print and broadcast news. A study in France found that people who were members in one or several associations were more politicized, although it did not make them more confident or civic (Mayer, 2003). Hooghe (1999) found that participation in associations affected social attitudes in the Flemish population of Belgium. Much of the discussion around social capital is consistent with an older model of how to look at relationships among these variables - socialization - although the criterion variable is less political knowledge or norms than social action. For a recent discussion of political socialization, see Dudley and Gitelson (2002) and other articles in a special issue of Applied Developmental Science (2002, Vol. 6, No. 4).
} 
related in structural pluralism theory, but a broader set of social characteristics is used.)

RQ2a: Which of the indicators of community "size" most strongly affect individuals' relationships with their community, general and political communication, and civic engagement?

RQ2b: Which of the indicators of community "size" most strongly affect associations among individuals' relationships with their community, general and political communication, and civic engagement?

Indicators of community size include neighborhood/community population, county population, and metropolitan population. People's relationships with their community include both affective (neighborhood attachment) and interpersonal (neighborhood ties) variables. People's general and political communication include the traditional media behaviors (e.g., reading the newspaper, watching television) and more targeted political communication variables (level of involvement in political communication network and the perceived climate for political communication). Civic engagement includes both membership in organizations and level of political activity.

Second, what aspects of the community are relevant besides size? In a national survey of community newspaper editors, reports of newspaper goals and functions were matched with community characteristics that included ascriptive factors (race, ethnicity, religious affiliation), achievementoriented factors (household income, education levels), and life-cycle variables (age, marital status), as well as size of the population of the community served by the papers (Jeffres, Cutietta, Sekerka, \& Lee, 2000); results showed that religious and racial heterogeneity were more important than the other achievement and life-cycle variables as influences on newspaper goals and functions. The importance of ethnicity is also noted in the work of Armstrong (2006), whose two-dimensional model includes leadership diversity and the traditional concept of community power. Other researchers not citing structural pluralism as a guiding force also have examined social heterogeneity for its impact on community behaviors. Following this line of research, we propose to examine similar measures of neighborhood or community heterogeneity in addition to the set of population variables as measures of the environment.

RQ3a: Which of the indicators of community heterogeneity most strongly affect individuals' relationships with their community, general and political communication, and civic engagement?

RQ3b: Which of the indicators of community heterogeneity most strongly affect associations among individuals' relationships with their community, general and political communication, and civic engagement? 
Third, much of the mass communication research mined in the tradition of Tichenor, Donohue, and Olien used the reflection model with direct links from community size to media performance, whereas others have used multiple measures that include size, occupation, and number of groups in the community (Demers, 1998). Coleman's modeling work shifted from structural research to social exchange models as he sought to make the micromacro transition (Marsden, 2005, p. 11). Coleman's work in later years centered on exchange theory, and he became an enthusiastic practitioner of rational choice theory in sociology. His assumption was that people were purposive actors using resources to pursue their interests. Following these assumptions, he studied structures of trust, social norms (Coleman, 1964), and collective behavior. Coleman (1990) argued that explanations of system behavior in terms of lower level constituent elements were more likely to be useful for interventions than those that remained at the system level. Those working in communication might heed this advice, as we're interested in how media are influenced by the environment and in turn influence people's civic engagement.

Further, we need to empirically investigate the complex set of relationships that may exist in the multifaceted environments in America today. For Coleman (1990), social structure included interdependencies, networks, authority structures, norms, and organizations. For communication scholars, additional issues are raised, because communication processes that operate to create interdependencies are themselves networks and can influence and be influenced by norms and organizations. At issue is how communication fits into this complex process of making the micro-macro transition.

Communication scholars, particularly those in mass communication, have generated a substantial body of work demonstrating the importance that media play in forming attachments to place. Rothenbuhler, Mullen, DeLaurell, and Ryu (1996) found newspaper reading made important contributions to community involvement and attachment, a relationship documented more than a generation ago by Janowitz (1952). Stamm and his colleagues (Stam, 1985; Stam, Emig, \& Hesse, 1997) found level of involvement correlated not only with reading the newspaper but also listening to the radio, watching television, and frequency of interpersonal communication within the community. Kasarda and Janowitz (1974) found community sentiment stronger the longer people lived in a community; attachment is also associated with people's perceptions of the quality of life available in their community (Campbell, Converse, \& Rodgers, 1976; Jeffres, Neuendorf, Bracken, \& Atkin, 2008). Most recently, opportunities for interaction have been linked to quality of life perceptions (Jeffres, Bracken, Jian, \& Casey, 2009). 


\section{METHODS}

A national telephone survey using a computer-assisted telephone interviewing system was conducted in late 2005 and early 2006 using a probability sample of households that yielded 477 respondents. The survey was introduced as the Civic Project, with an emphasis on communities and technology. The 20 -minute survey had a cooperation rate of about $27 \%$, comparable to that achieved by surveys of similar length. Following are the measures of concepts.

\section{The Community Environment: Size of Population}

Respondents were asked for the zip code in which they lived. This was matched with the most recent population projections available from the U.S. Census Bureau website. First, the actual population of the zip code and of the community in which the zip code was located were recorded. Next, the population of the county was recorded. Then the Census Bureau's list of metropolitan areas was used to locate respondents in a metropolitan area, and that population was recorded. ${ }^{6}$

\section{The Community Environment: Heterogeneity of Population}

Following the literature, we recorded population breakdowns of communities for age, ethnicity, occupation, household income, and marital status using the Census categories (e.g., the percentage Caucasian, African American, Asian, Hispanic, American Indian, other ethnicity, and mixed). Then, using Blau's (1977) formula for heterogeneity across categories, we computed heterogeneity measures for each variable and summed up the individual scores for an overall heterogeneity measure of the population. ${ }^{7}$

\footnotetext{
${ }^{6}$ Respondents earlier were asked to identify which of the following best describes where they live - in a central city neighborhood of a metropolitan area, in a nearby suburb of a metro area, in a more distant suburb of a metro area, in a fair-sized city outside a metro area, in a small town outside a metro area, or in the country. A check on respondents' perceptions of their community environment is found in the appendix, where the population and heterogeneity measures are broken down by these categories. We see that those who claim to live in small towns on average do have smaller populations when categorized by U.S. Census Bureau data, whereas those in larger cities have larger averages. Those who reported living in the country were assigned a population of 10 to account for some nearby neighbors, although some respondents' zip codes clearly placed them in distant rural areas according to the Mapquest photos images.

${ }^{7}$ Blau's formula for heterogeneity provides the equivalent to statistical variance when the categories are ordered or interval data: Heterogeneity $=1-\left[\left(\right.\right.$ category $1^{2}+$ category $2^{2}+$ category $3^{2}+$ category $\left.\left.^{2}\right) /(\text { category } 1+\text { category } 2+\text { category } 3+\text { category } 4)^{2}\right]$. When the population is concentrated into a single category, for example, all Caucasian or all African American, the resulting figure is small, but when the population is spread more equally across the available categories, the figure is larger.
} 
Respondents were asked which of a set of options described where they lived, from central city neighborhoods of metro areas to suburbs, small towns, and the country. The census population and heterogeneity measures are broken down by these designations in the appendix.

Two measures of civic engagement were used: political activity and involvement in organizations.

\section{Political Activity}

Items used to measure this concept correspond to the gladiatorial, transitional, and spectator activities in Milbraith's (1965) political involvement hierarchy. Respondents were asked whether they had participated in the past couple years in each of a variety of ways people get involved in their community, government, or politics, including attending meetings of your town or city council, or attending a political meeting or rally; wearing a button or putting a sticker on your car; voting in the 2004 presidential election; participating in a march or rally; helping circulate or signing a petition; soliciting political funds; contributing money to a party or candidate. An additive scale was constructed ( $\alpha=.74$; eight items, $M=2.93, S D=2.1)$.

\section{Organizational Involvement}

Respondents were asked whether they belonged to each of the following types of organizations (group names and the percentages of respondents belonging): business or civic groups like Kiwanis or Rotary (16\%); religious organizations $(54 \%)$; charity or volunteer organizations $(45 \%)$; ethnic or racial organizations (11\%); PTA or other school-related groups (26\%); political clubs or organizations (15\%); social clubs such as card playing, music, hobbies, book club (38\%); youth groups like scouts or children's sports $(24 \%)$; professional or work-related organizations $(30 \%)$; neighborhood associations such as block clubs; any other types of organizations not mentioned $(21 \%)$. A sum was computed across the groups for an index $(\alpha=.76$; $M$ of 11 -item index $=2.99, S D=2.5){ }^{8}$

Two measures of people's relationship with their community were assessed: one measuring people's affective attachment connections with community and the other measuring interpersonal ties and links to people in the community.

\footnotetext{
${ }^{8} \mathrm{~A}$ factor analysis yielded three dimensions, the first accounting for $30 \%$ of the variance reflected membership in civic, political, professional-work related, neighborhood, and other organizations; the second accounting for $11 \%$ of the variance reflected membership in school and youth groups; and the third accounting for $9 \%$ of the variance reflected membership in religious and charity-volunteer groups.
} 


\section{Neighborhood Attachment}

Four items tapped the strength of one's attachment to the neighborhood in which they live, with respondents using a 0-to-10 scale, ranging from 0 (completely disagree) to 5 (neutral) to 10 (completely agree) for the following statements: I'd feel lost if I had to move from my neighborhood, I feel I'm a part of the community in which I live, I feel a strong identification with my community, and I enjoy living in my neighborhood. All items were standardized and summed for a scale $(\alpha=.83 ; M=26.9, S D=9.9)$.

\section{Strength of Neighborhood Ties}

Neighborhood ties refer to the interpersonal connections (relatives, friends, neighbors) and the nature of those links (e.g., interpersonal communication). A couple of these items were taken from Wallin's scale for neighborliness. One item asked how many of the homes of their 10 closest neighbors they had visited. A second item asked how many of the 10 closest neighbors they know by name or well enough to say hello when they see them on the street, and a final item asked what percentage of one's closest friends live in the same community: almost all, three fourths, about half, one fourth, less than that, or none. All items were standardized and summed up for a scale, with a smaller alpha than desirable but reasonable for a scale with only three items $(\alpha=.65$; three items, $M=.01, S D=2.3$; no. neighbors know and no. homes visited correlated at .61, $p<.001$; percentage of friends living in same community correlated at .28 with no. homes visited and .26 with no. neighbors know, both correlations statistically significant, $p<.01)$.

Three sets of communication variables were included: involvement in a political discussion network, the perceived political communication climate, and mass media use.

\section{Political Discussion Network}

Five items measured the size, heterogeneity, and frequency of involvement in a political discussion network. Respondents were asked to use a 0-to-10 scale to tell how much they agreed with each of the following two items, ranging from 0 (completely disagree) to 5 (neutral) to 10 (completely agree): I generally discuss political candidates and issues with neighbors at election time, and I generally discuss political candidates and issues with family and friends at election time. Another item asked how many days in the past week the respondent engaged in political discussion with friends and family: never, once, a couple times, almost every day, or several times a day. An additional item asked how often one discusses politics with people whose 
political views are different from yours: almost never, seldom, sometimes, or frequently. A final item asked about how many people one discusses politics with on a regular basis: none, 1,2 or 3,5 to 10 , or more than that. Responses to all items were standardized and scores summed up for a scale $(\alpha=.81$; five items, $M=.03, S D=3.8)$.

\section{Political Communication Climate}

Several items tapped the climate for informal communication across contexts. Respondents were asked how comfortable they are striking up a conversation with a stranger on the street: very comfortable, somewhat comfortable, somewhat uncomfortable, or very comfortable. They used the same scale to indicate comfort in talking about politics, religion, or other personal matters with neighbors, and again with talking about such personal things with people at work. In addition, respondents used a 0-to-10 scale, ranging from 0 (completely disagree) to 5 (neutral) to 10 (completely agree), to indicate how much they agreed with an item that measured the perceived climate for communication in more formal public settings: I'd feel comfortable voicing a complaint at a public meeting in my community. Responses were standardized and summed up for a scale; although the alpha is somewhat below the desirable cutoff, the intercorrelations are all sufficiently strong to merit continued use of the scale as a summary measure rather than examining items individually ( $\alpha=.60$; four items, $M=.04$, $S D=2.7$; correlations between items range from .20 to .34 , all $p<.001$ ).

\section{Media Use}

The traditional items were used to tap how many days in the past week people read the newspaper, how much time they spent watching television yesterday, how often they usually watch the news on television, how much time they spent listening to the radio yesterday, and how often they go on the Internet at home or at work (from never to several times each day).

\section{Social Categories}

Traditional items measured gender, ethnicity, marital status, age, level of education, and household income.

\section{RESULTS}

The first research question tests the assumption that population and occupational differentiation are related in structural pluralism theory, extended 
to additional measures of demographic heterogeneity. In research that looks at small towns separate from metropolitan areas, the relationship is clearer than it might be for a broader range of communities. The impact of population could occur through differentiation at the metropolitan level but be balanced in part by heterogeneity/homogeneity at the neighborhood level. Thus, we examined the relationship between size and our measures of heterogeneity in the immediate neighborhood as measured by zip code. As Table 1 shows, most of the population measures are correlated with the heterogeneity measures. The summary measure of heterogeneity that aggregates the separate heterogeneity measures is correlated with city population $(r=.24, p<.001)$, county population $(r=.24, p<.001)$, and metro population $(r=.26, p<.001)$. However, the pattern is not uniform. Age heterogeneity is negatively correlated with all three population measures, and occupational heterogeneity is negatively correlated with county and metro population; thus, people who live in metro or densely populated counties are more likely to live in more homogeneous neighborhoods in terms of occupation. Income heterogeneity is positively correlated with the city population but neither of the other two. Thus, although size of population affects heterogeneity, the pattern is not uniform and the latter not merely conduits for influences of population on subsequent individual behaviors. The pattern reflects the fact that neighborhoods in metro areas tend to reflect status.

Given the relationship between size and heterogeneity, we followed up to see how each of those was related to people's community relationships, communication patterns, and civic engagement. Our second research question

TABLE 1

Relationships Between Population and Measures of Heterogeneity

\begin{tabular}{lccc}
\hline Community heterogeneity & City population & County population & Metro population \\
\hline Marital heterogeneity & $.22^{* * *}$ & $.14^{*}$ & $.17^{* *}$ \\
Income heterogeneity & $.17^{* *}$ & $.10^{\dagger}$ & .06 \\
Education heterogeneity & $.17^{* *}$ & $.17^{* *}$ & $.18^{* * *}$ \\
Age heterogeneity & $-.16^{* *}$ & $-.21^{* * *}$ & $-.23^{* * *}$ \\
Racial-ethnic heterogeneity & $.25^{* * *}$ & $.34^{* * *}$ & $.36^{* * *}$ \\
Occupational heterogeneity & -.08 & $-.25^{* * *}$ & $-.26^{* * *}$ \\
Summary heterogeneity & $.24^{* * *}$ & $.24^{* * *}$ & $.26^{* * *}$ \\
\hline
\end{tabular}

Note. The measures of heterogeneity are computed on the community census data as represented by the zip code. The city population refers to the town in which the zip code is located, the county population refers to the county in which the zip code is located, and the metro population to any corresponding metro area identified through an inspection using Mapquest's aerial maps and other sources.

${ }^{\dagger} p<.10 .{ }^{*} p<.05 .{ }^{* *} p<.01 .{ }^{* * *} p<.001$. 
asked if any of the indicators of community "size"-neighborhood/ community, county, or metropolitan population - affect people's relationships with their community, their media use and political communication, or their civic engagement. As Table 2 shows, none of the population measures are correlated with community relationships - neighborhood ties or attachment. Community population is correlated with only one communication variable, a positive relationship with watching television news, and one measure of civic engagement, a negative relationship with organizational involvement. The county population is positively correlated to frequency of Internet use and organizational involvement. It is metropolitan population that enters into the most significant correlations: political communication network $(r=.11, p<.05)$, frequency read the newspaper $(r=.13, p<.05)$, frequency watch TV news $(r=.10, p<.05)$, and organizational involvement $(r=.10, p<.05)$. Thus, it appears that living in a county with a larger population or in a metro area gives people access to more attractive or appealing news media and organizational options, leading to more frequent behaviors at the individual level. People also seem to discuss politics more when they live in metro areas. In general, the impact of population directly on any of the three sets of variables - community relationships, communication, and civic engagement - is unimpressive.

The next research question (RQ2b) asked if any of the indicators of community "size" affect relationships between people's community ties

TABLE 2

Relationships Between Population and Other Variables

\begin{tabular}{|c|c|c|c|}
\hline & $\begin{array}{l}\text { Community } \\
\text { population }\end{array}$ & $\begin{array}{c}\text { County } \\
\text { population }\end{array}$ & $\begin{array}{c}\text { Metropolitan } \\
\text { population }\end{array}$ \\
\hline \multicolumn{4}{|l|}{ Relationships with community } \\
\hline Neighborhood attachment & -.02 & -.10 & .01 \\
\hline Neighborhood ties & -.04 & -.02 & .00 \\
\hline \multicolumn{4}{|l|}{ Communication variables } \\
\hline Political communication network & -.03 & .06 & $.11^{*}$ \\
\hline Perceived political communication climate & -.03 & .02 & .03 \\
\hline Freq. read newspaper & -.05 & $.08^{\dagger}$ & $.13^{*}$ \\
\hline Freq. watch TV news & $.10^{*}$ & $.08^{\dagger}$ & $.10^{*}$ \\
\hline Hours watch TV yesterday & .03 & .02 & .02 \\
\hline Time spent listening to radio yesterday & .01 & -.06 & $-.07^{\dagger}$ \\
\hline Freq. visit Internet at home or at work & -.01 & $.10^{*}$ & $-.07^{\dagger}$ \\
\hline \multicolumn{4}{|l|}{ Civic engagement } \\
\hline Political activity & -.03 & .04 & .06 \\
\hline Organizational involvement & $-.08^{\dagger}$ & $.09^{*}$ & $.10^{*}$ \\
\hline
\end{tabular}

Note. Freq. $=$ frequently.

${ }^{\dagger} p<.10 .{ }^{*} p<.05$. 
and attachment, their media use and political communication and their civic engagement through organizational membership, and political activity. Table 3 includes both the bivariate relationships and partial correlations controlling for population. First, there is a strong pattern of positive correlations between the two sets of variables representing (a) civic engagement and community relationships and (b) communication measures. Those most tied to their community and most engaged in civic activities read the newspaper more often, discuss politics more frequently, and think the climate for such discussions is more positive. Time spent watching television is negatively related with civic engagement but not correlated with community relationships, whereas watching the news on television is positively related to both neighborhood attachment and ties but not related to civic engagement. Those who frequent the Internet more often are more involved in civic activities but show less neighborhood attachment. Controlling for the three population measures has little impact on the pattern. In one instance, controlling for population increases the correlation between perceptions of the political communication climate and newspaper readership, neighborhood attachment, and neighborhood ties. Again, the impact of population is negligible.

Given the fairly limited impact of population measures, we moved to examine the impact of community heterogeneity at the neighborhood level. The third research question (RQ3a) asked if the dimensions of community heterogeneity are related to measures of media use, political communication, community relationships, and civic engagement. Table 4 shows that some negative relationships appear between civic engagement and heterogeneity, and the summary measure of heterogeneity is negatively correlated with organizational involvement. Greater political activity is exhibited by people who live in neighborhoods that are more homogeneous in terms of age or occupation. When population measures are controlled (not shown in Table 4), the relationships persist. Similarly, both measures of community relationships are negatively associated with the summary heterogeneity measure, and the chief influences appear to be racial-ethnic, educational, and marital heterogeneity. Some of the media use is related to heterogeneity; time spent watching television is greater in more diverse neighborhoods. Involvement in a stronger political communication network is associated only with age heterogeneity $(r=-.12, p<.05)$.

The fourth research question asked if measures of community heterogeneity affect the relationship between communication variables, civic engagement, and community relationships. The pattern that emerges in Table 5 is similar to that found in Table 3 where population is controlled. The relationships between communication variables and measures of civic engagement and community relationships persist, with positive relationships 


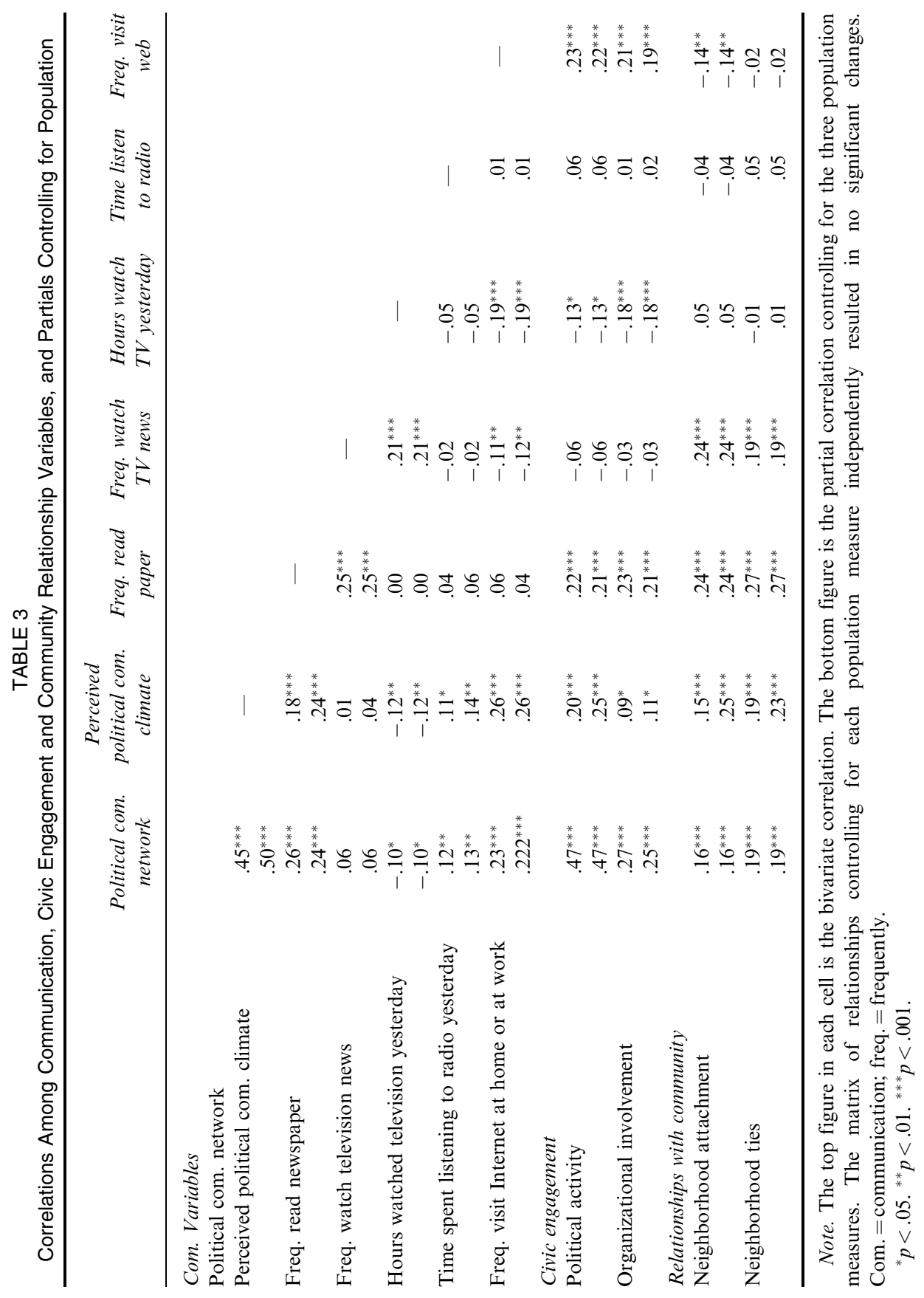




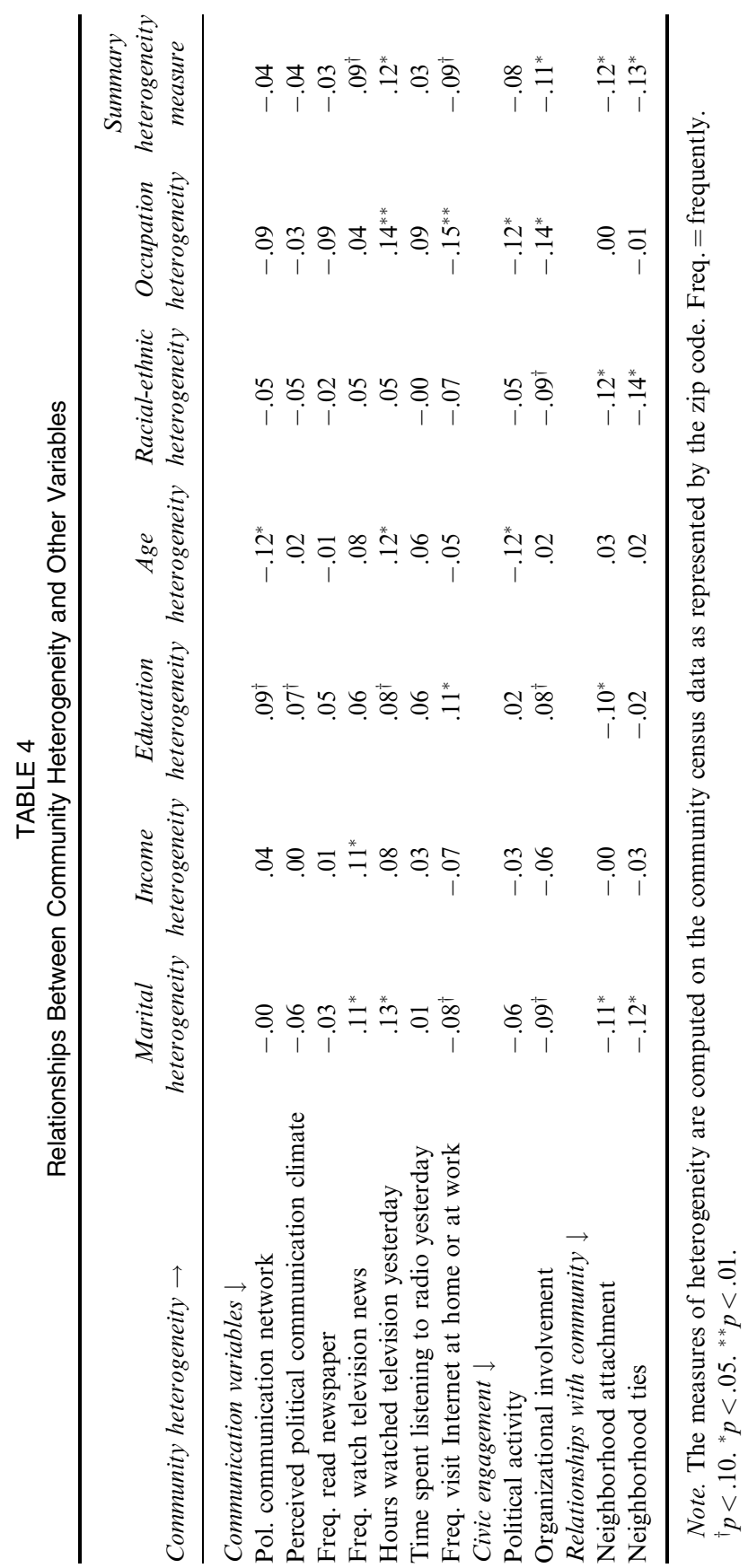


TABLE 5

Correlations Among Communication, Civic Engagement and Community Relationship Variables, and Partials Controlling for Heterogeneity, Social Categories

\begin{tabular}{|c|c|c|c|c|}
\hline & \multicolumn{2}{|c|}{ Civic engagement $\downarrow$} & \multicolumn{2}{|c|}{ Relationships with community $\downarrow$} \\
\hline & $\begin{array}{l}\text { Political } \\
\text { activity }\end{array}$ & $\begin{array}{c}\text { Organizational } \\
\text { involvement }\end{array}$ & $\begin{array}{c}\text { Neighborhood } \\
\text { attachment }\end{array}$ & $\begin{array}{l}\text { Neighborhood } \\
\text { ties }\end{array}$ \\
\hline \multicolumn{5}{|l|}{ Communication variables $\downarrow$} \\
\hline \multirow{2}{*}{$\begin{array}{l}\text { Political communication } \\
\text { network }\end{array}$} & $.47^{* * *}$ & $.26^{* * *}$ & $.16^{* *}$ & $.19^{* * *}$ \\
\hline & $.43^{* * *}$ & $.21^{* * *}$ & $.16^{* *}$ & $.16^{* * *}$ \\
\hline \multirow{2}{*}{$\begin{array}{l}\text { Perceived political } \\
\text { communication climate }\end{array}$} & $.20^{* * *}$ & $.09^{\dagger}$ & $.15^{* *}$ & $.19^{* * *}$ \\
\hline & $.12^{*}$ & .02 & $.20^{* * *}$ & $.17^{* * *}$ \\
\hline \multirow[t]{2}{*}{ Freq. read newspaper } & $.22^{* * *}$ & $.22^{* * *}$ & $.24^{* * *}$ & $.27^{* * *}$ \\
\hline & $.21^{* * *}$ & $.23^{* * *}$ & $.12^{*}$ & $.20^{* * *}$ \\
\hline \multirow[t]{2}{*}{ Freq. watch television news } & -.05 & -.02 & $.25^{* * *}$ & $.20^{* * *}$ \\
\hline & -.03 & .00 & $.13^{*}$ & $.15^{* *}$ \\
\hline \multirow{2}{*}{$\begin{array}{l}\text { Hours watched television } \\
\text { yesterday }\end{array}$} & $-.12^{*}$ & $-.17^{* * *}$ & .06 & .01 \\
\hline & -.06 & $-.11^{*}$ & .01 & .00 \\
\hline \multirow{2}{*}{$\begin{array}{l}\text { Time spent listening to } \\
\text { radio yesterday }\end{array}$} & .06 & .01 & -.04 & .05 \\
\hline & .08 & .03 & .01 & $.08^{\dagger}$ \\
\hline \multirow{2}{*}{$\begin{array}{l}\text { Freq. visit Internet at home } \\
\text { or at work }\end{array}$} & $.23^{* * *}$ & $.20^{* * *}$ & $-.15^{* *}$ & -.04 \\
\hline & $.12^{*}$ & $.10^{*}$ & $-.09^{*}$ & -.06 \\
\hline \multicolumn{5}{|l|}{ Civic engagement $\downarrow$} \\
\hline \multirow[t]{2}{*}{ Political activity } & & & .03 & $.11^{*}$ \\
\hline & & & .06 & $.10^{*}$ \\
\hline \multirow[t]{2}{*}{ Organizational involvement } & & & .01 & $.20^{* * *}$ \\
\hline & & & .06 & $.20^{* * *}$ \\
\hline
\end{tabular}

Note. The top figure in each cell represents the partial correlation between the individual-level variables controlling for the summary measure of community heterogeneity. The bottom figure also controls for heterogeneity as well as individual social categories (age, gender, education level, ethnicity, and marital status). Freq. = frequently.

${ }^{\dagger} p<.10 .{ }^{*} p<.05 .{ }^{* *} p<.01 .{ }^{* * *} p<.001$.

between political activity and both newspaper readership and Internet use and a negative partial correlation with time spent watching television; the pattern is repeated with organizational involvement. Also, those who are most involved in a political communication network and those who perceive the political communication climate more favorably are more politically active and involved in organizations. The pattern with community relationships is similar, but with a positive impact from watching TV news; thus, stronger neighborhood attachment and ties are associated with watching TV news more often, reading the newspaper more often, involvement in a stronger political communication network, and a more favorable perception of the climate for political communication. Internet use is negatively associated with neighborhood attachment. Neighborhood ties are positively 
related to political activity and organizational involvement. When individuallevel social categories are controlled, again the pattern generally persists, with a couple exceptions. The negative relationship between political activity and time spent watching television drops out, as does the near-significant relationship between organizational involvement and perceived political communication climate. When the three population measures are added to the neighborhood heterogeneity measures and the individual social categories as controls, there is virtually no change in the pattern of relationships. Clearly the environmental impact at the community level is minimal for this set of variables.

Next, we reconfigured the relationships discovered in the preceding analyses in a coherent model and used structural equation modeling analysis to assess the overall fit of the specified relationships among environmental influences, people's communication patterns and community relationships, and civic engagement (see Figure 1). In the tested model, there were five latent constructs with multiple indicators and four single-item observed

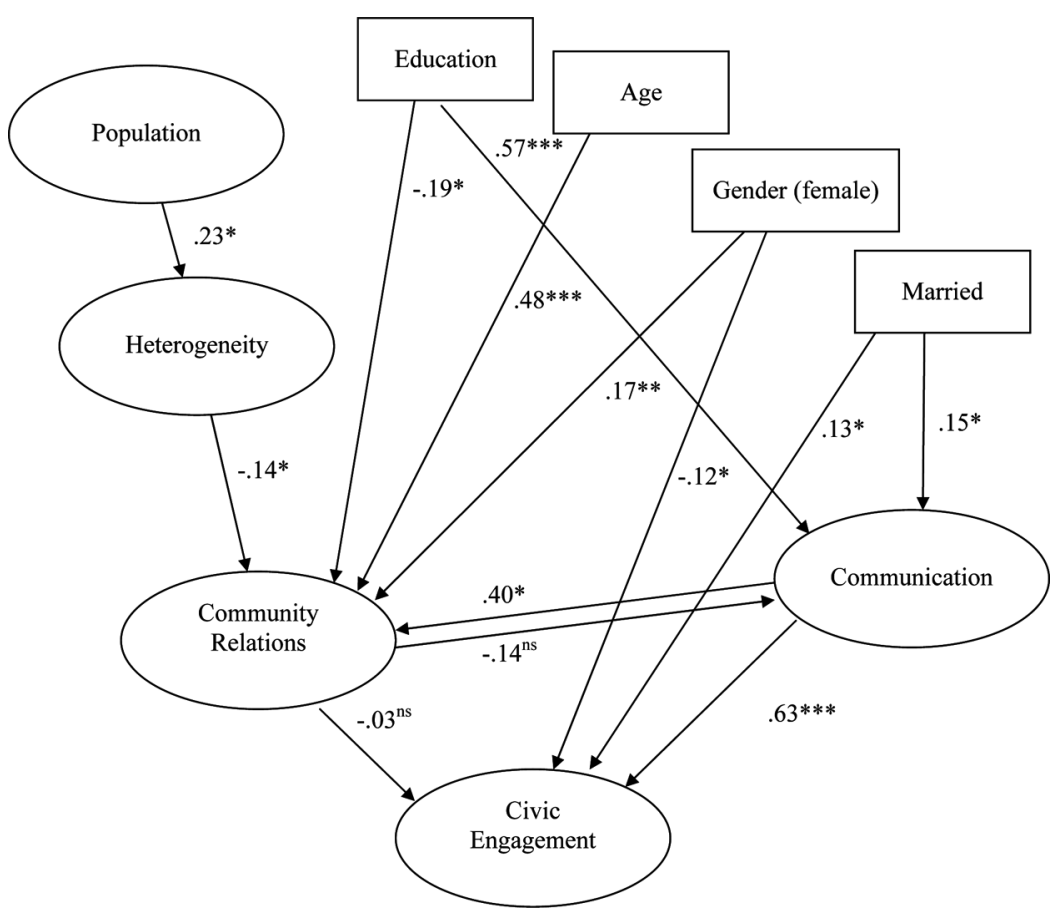

FIGURE 1 Structural equation model. Note. Model $\chi^{2}(161)=662, p<.001$; comparative fit index $=.97$; root mean square error of approximation $=.08 .{ }^{*} p<.05 .{ }^{* *} p<.01 .{ }^{* * *} p<.001$. 
variables. The five latent constructs were population (two indicators - city population, county population), heterogeneity (six indicators-marital heterogeneity, income heterogeneity, education heterogeneity, age heterogeneity, racial-ethnic heterogeneity, and occupation heterogeneity), communication (four indicators-political communication network, newspaper readership, television exposure, and level of Internet use), community relationships (two indicators - neighborhood attachment and neighborhood ties), and civic engagement (two indicators - political activity and organizational involvement). To control for social categories, a first run of the model included the single-item variables of gender, marital status, age, and education; only those effects that emerged as significant in this first analysis were retained in the final model. The final model is shown in Figure 1.

A maximum likelihood model estimation was conducted via the statistical package AMOS. Using the comparative fit index (CFI) and the root mean square error of approximation (RMSEA) as main indicators of model fit, the analysis found the model to have achieved a reasonable fit. The CFI was .97 , and the RMSEA was .080 (with a $90 \%$ confidence interval of .074 , $.087)$, meeting or exceeding the standard criteria for CFI (.90 or greater) and RMSEA (.08 or less; Byrne, 2001). The overall chi-square was statistically significant, $\chi^{2}(161)=662$, but the analysis' large sample size makes the interpretation of this significance inconclusive. All four endogenous constructs were found to have significant overall predictions (i.e., significant $R^{2} \mathrm{~s}$ ). The model was able to account for $5 \%$ of the variance in heterogeneity, $28 \%$ of the variance in communication (with, by the way, a negative contribution by TV viewing; all other communication indicators showed positive loadings), $29 \%$ of the variance in community relations, and $45 \%$ of the variance in civic engagement.

Figure 1 displays the standardized path coefficients for the latent model. As expected, heterogeneity was positively associated with population size $(\beta=.23, p=.05)$, with heterogeneity contributing significantly and negatively to the prediction of community relations $(\beta=-.14, p=.05)$. Three social category variables also bore significantly contributions to community relations, with education demonstrating a negative relationship $(\beta=-.19$, $p=.05$ ), age a positive relationship $(\beta=.48, p<.05)$, and gender (female) a positive relationship $(\beta=.17, p=.05)$. Communication was also found to significantly predict community relations, with a positive association $(\beta=.40, p=.05)$. Standardized path coefficients are reported, with significance tests for indirect and direct effects, in Table 6. Only one of the two indirect paths from education to civic engagement, that of education $\rightarrow$ communication $\rightarrow$ civic engagement, is significant.

Although it was anticipated that a reciprocal causal relationship would exist between communication and community relations, this was found 
TABLE 6

Decomposition of Indirect and Effects for the Structural Equation Model

\begin{tabular}{|c|c|c|c|}
\hline Dependent variable & Predictor variables & Indirect effects & Direct effects \\
\hline \multicolumn{4}{|l|}{$R^{2}=.05$} \\
\hline Community & Population & -.03 & - \\
\hline Relations & Diversity & .01 & $-.14(2.17)^{*}$ \\
\hline \multirow[t]{5}{*}{$R^{2}=.29$} & Education & $.22(2.09)^{*}$ & $-.19(-1.98)^{*}$ \\
\hline & Age & -.02 & $.48(5.29)^{* * *}$ \\
\hline & Gender (female) & -.01 & $.17(2.97)^{* *}$ \\
\hline & Married & .06 & - \\
\hline & Communication & -.02 & $.40(2.40)^{*}$ \\
\hline Communication & Population & .004 & - \\
\hline \multirow[t]{6}{*}{$R^{2}=.28$} & Diversity & .02 & - \\
\hline & Community relations & .01 & -.14 \\
\hline & Education & .01 & $.57(4.26)^{* * *}$ \\
\hline & Age & -.06 & - \\
\hline & Gender (female) & -.02 & - \\
\hline & Married & -.01 & $.15(2.20)^{*}$ \\
\hline Civic & Population & .004 & - \\
\hline engagement & Diversity & .02 & - \\
\hline \multirow[t]{6}{*}{$R^{2}=.45$} & Community relations & -.08 & -.03 \\
\hline & Education & $.35(2.90)^{a_{* *}}$ & - \\
\hline & Age & -.05 & - \\
\hline & Gender (female) & -.02 & $-.12(-2.30)^{*}$ \\
\hline & Married & .09 & $.13(2.27)^{*}$ \\
\hline & Communication & -.05 & $.63(3.98)^{* * * *}$ \\
\hline
\end{tabular}

Note. Standardized path coefficients are reported, with significance tests for indirect and direct effects. For indirect effects, the test reported is the Sobol test (Preacher \& Leonardelli, 2003). For direct effects, the test is the critical value (assessed via the $t$ ).

${ }^{a}$ Only one of the two indirect paths from education to civic engagement, that of education $\rightarrow$ communication $\rightarrow$ civic engagement, is significant, and the Sobel test is reported for that path only.

${ }^{*} p<.05 .{ }^{* *} p<.01 .{ }^{* * *} p<.001$.

not to be the case. The path leading from community relations back to communication was not significant $(\beta=-.14, n s)$. Two social category variables were found to be significant positive predictors of communication: education $(\beta=.57, p<.05)$ and married $(\beta=.15, p=.05)$.

In the prediction of civic engagement, three significant predictors emerged. However, an anticipated relationship between community relations and civic engagement was found to be nonsignificant $(\beta=-.03, n s)$. The three significant predictors were gender (female) $(\beta=-.12, p=.05)$, married $(\beta=.13, p=.05)$, and communication $(\beta=.63, p<.05)$. 
In addition, we conducted hierarchical regressions predicting political activity and organizational involvement, ${ }^{9}$ as well as a summary measure combining the two measures of civic engagement. ${ }^{10}$

\title{
DISCUSSION
}

Results corresponding to our research questions provide a less-than-
impressive endorsement of the linear hypothesis and/or structural plural-
ism. The data do tend to support the link between community size as

\begin{abstract}
${ }^{9}$ Contact the authors for a copy of these tables. Variables were entered in the following blocks: heterogeneity and population measures, followed by social categories, then community relations variables, then media use, and finally the two measures of interpersonal communication (political communication network and perceived political communication climate). The community level measures had no significant impact on political activity. With census data and social categories already in the equation, newspaper readership and the political communication network scale were significant. However, community factors are important in predicting organizational involvement, and the key variables include both heterogeneity and city population. Those who live in more diverse communities and larger cities are involved in fewer organizations. Men, married people, and those with more education show greater organizational involvement regardless of the size or heterogeneity of their community. The ethnic significance drops out with community-level controls in place. Similarly, those who watch less television and read the paper more often are involved in more organizations, regardless of community heterogeneity or population, and the same pattern is found for those who discuss politics more often, perceive a more favorable climate for discussing political issues, and have stronger community ties. Again, the order of the blocks was varied to see if variables disappeared or surfaced as significant predictors. We find that the influence of some variables drops below statistical significance. With census and social categories already in the equation, the negative impact of time spent watching TV drops just below significance with neighborhood ties and the political discussion network entered earlier; it appears television's impact is indirect through interpersonal ties and discussion, not time displacement. This is consistent with some of the research in social capital.

${ }^{10}$ Finally, the two measures of political participation and organizational involvement, which are highly correlated $(r=.61, p<.001)$, were standardized and summed up for a summary measure of civic engagement. The same regression strategy was followed in predicting the summary measure, with a similar pattern of significant predictors found. Internet use emerges as a significant predictor in both regressions, including that with community-level population and heterogeneity controlled. Thus, there may be some additive component to civic activities stimulated by Internet use. In the final equation with census data included, married marital status is a significant predictor $(\beta=.18, p<.001)$; other significant predictors are neighborhood ties $(\beta=.11$, $p<.04)$, political discussion network $(\beta=.34, p<.001)$, and newspaper readership $(\beta=.18$, $p<.001)$. When community-level variables are excluded, perceptions of the political communication climate $(\beta=-.12, p<.03)$, time spent watching TV $(\beta=-.10, p<.04)$, and White ethnicity $(\beta=-.10, p<.03)$ emerge as significant predictors. Thus, although the heterogeneity and population variables exert their influence through other variables, they fail to appear as significant predictors in the final equation when included.
\end{abstract}


indicated by three population measures and community heterogeneity measured in terms of occupation, ethnicity, age, education, income, and marital status. But the pattern is not uniform across all measures of heterogeneity, so we should not expect heterogeneity to act as a conduit for influences of population on people's behaviors. Metropolitan areas themselves vary in terms of their density and their patterns of growth, some with integrated neighborhoods and some quite segregated. Neighborhoods in metro areas also tend to reflect status for a variety of reasons. Thus, when we look at the impact of structural factors, we need to take into account different "levels," from the neighborhood up to the metropolitan area. People act out their involvement in neighborhoods and more immediate surroundings, a fact researchers often tend to ignore. Regions also could be a factor in studying some behaviors.

The next two research questions follow from these results, asking whether indicators of population or heterogeneity impact the measures of people's communication, community connections, and people's civic engagement, or relationships among those three sets of variables.

None of the population measures are correlated with people's community attachment or ties, but some significant correlations are noted for communication and civic engagement. More frequent newspaper readership and more frequent viewing of news on television are found in more populated areas, and there's an indication that political communication is stronger in larger metropolitan areas. A mixed pattern is found for Internet use, and those in metro areas show higher organizational involvement.

We also find that population has little impact on the pattern of generally positive relationships among civic engagement, community relationships, and communication measures. Those more politically active and involved in organizations show stronger attachment to neighborhood and more neighborhood ties. Newspaper reading is related to civic engagement and community relationships, whereas web visits are related positively to civic engagement but negatively related to neighborhood attachment. The interpersonal political communication network and perceptions of the political communication climate are related to civic engagement and community relationships.

Relative to the fairly muted impact of population, heterogeneity at the community or neighborhood level is noteably stronger. The summary scale of heterogeneity is positively related to the amount of time spent watching television and negatively related to Internet use. Furthermore, overall heterogeneity is negatively associated with civic engagement and both neighborhood attachment and ties. Thus, although civic engagement may be higher in larger metropolitan areas, the impact of heterogeneity at the neighborhood level is negative. Of the individual measures of heterogeneity, 
racial-ethnic heterogeneity and marital status heterogeneity show the clearest pattern of negative relationships with civic engagement and community relationships.

When community heterogeneity is controlled, there is little change in the pattern of relationships among measures of people's communication behaviors, community attachment and ties, and civic engagement. The positive relationships between civic engagement, community relationships and newspaper readership, and the political communication network persist. The magnitude of the relationship between Internet use and civic engagement does decline substantially but still is significant, as does a negative correlation with neighborhood attachment.

Finally, analysis of our structural model provides evidence that the "linear hypothesis" can be combined with structural pluralism, with sizemeasured by population-impacting heterogeneity, which influences the relationships that people have with their community. Concurrently, the social categories that place people within social structures (some varying through life on the basis of achievements, others reflecting one's place in the life cycle and characteristics of birth) influence people's communication patterns and community relationships. A dynamic model with data capturing changes across time would be necessary to sort out this complex of individual and community structural constraints; thus, education influences community relationships negatively and communication patterns positively at a point in time, whereas married people are more civically engaged and more frequent readers of newspapers. Men are more involved in civic and political activities, whereas women are more tied to their communities. As people move into different communities and settle, they continue to age, and perhaps advance their education and change their marital status, and communities grow and diversify. Although we do know that people select homes on the basis of schools when they have children, we also know that jobs are a constraint. These same social categories also affect people differentially through time. Given the dynamic changes affecting cities today (emptying neighborhoods in central cities, challenged first-ring suburbs, little job growth, and more limited mobility), we need to pay more attention to this set of relationships between community level and individual social constraints. Stamm's (1985) effort to see how people's communication patterns - specifically newspaper readership - are related to community ties in a dynamic model provides an example of the type of work that is needed.

The relationship between communication and community relationships is a complicated one. We posited a reciprocal relationship between the two sets of variables but the influence of communication emerges as the important one in this static model. As it turns out, communication variables are quite significant in predicting civic engagement, whereas the path from 
community relations falls below significance within the model, suggesting that community relationships may impact different types of civic engagement than those featured here. Examining the communication variables impacting civic engagement, we can say that people's civic engagementbelonging to organizations and level of political activity-is positively impacted by the level of one's involvement in a political communication network, more frequent readership of a newspapers, lower television exposure, and more frequent Internet use. Clearly, the pattern of relationships confirms the centrality of communication to practice of civic life.

This study has a national focus, but it represents a slice in time. With a rapidly changing media landscape and equally significant changes in demographics and urban centers, we need to expand our communication measures to include use of the Internet and mobile technologies and how they affect people's relationships with their communities and their involvement in the public arena. We also need to consider the breadth and stability of the concept of civic engagement, particularly across the life cycle.

\section{REFERENCES}

Abrahamson, M., \& Carter, V. J. (1986). Tolerance, urbanism and religion. American Sociological Review, 51, 287-294.

Armstrong, C. L. (2006). Revisiting structural pluralism: A two-dimensional conception of community power. Mass Communication and Society, 9, 287-300.

Armstrong, C. L. (2008). Exploring a two-dimensional model of community pluralism and its effects on the level of transparency in community decision making. Journalism and Mass Communication Quarterly, 85, 807-822.

Berkowitz, D. (2007). Professional views, community news: Investigative reporting in small US dailies. Journalism, 8, 551-558.

Berkowitz, D., \& TerKeurst, J. V. (1999). Community as interpretive community: Rethinking the journalist-source relationship. Journal of Communication, 49, 125-136.

Blau, P. H. (1977). Inequality and heterogeneity: A primitive theory of social structure. New York: The Free Press.

Byrne, B. M. (2001). Structural equation modeling with AMOS: Basic concepts, applications, and programming. Mahwah, NJ: Erlbaum.

Campbell, A., Converse, P., \& Rodgers, W. (1976). The quality of American life. New York: Russell Sage.

Coleman, J. S. (1961). Analysis of social structures and simulation of social processes with electronic computers. Educational and Psychological Measurement, 21, 203-218.

Coleman, J. S. (1964). Collective decisions. Sociological Inquiry, 34, 16-181.

Coleman, J. S. (1980). The structure of society and the nature of social research. Knowledge, 1 , 333-350.

Coleman, J. S. (1988). Social capital in the creation of human capital. American Journal of Sociology, 95, S95-S120.

Coleman, J. S. (1990). Foundations of social theory. Cambridge, MA: Harvard University Press. 
Demers, D. K. (1994). Relative constancy hypothesis, structural pluralism and national advertising expenditures. Journal of Media Economics, 7, 31-48.

Demers, D. K. (1996). Corporate newspaper structure, editorial page vigor and social change. Journalism Quarterly, 73, 857-877.

Demers, D. K. (1998). Structural pluralism, corporate newspaper structure, and news source perceptions: Another test of the editorial vigor hypothesis. Journalism and Mass Communication Quarterly, 75, 572-592.

Donohue, G. A., Olien, C. N., \& Tichenor, P. J. (1985). Reporting conflict by pluralism, newspaper type and ownership. Journalism Quarterly, 62, 489-499, 507.

Donahue, G. A., Olien, C. N., \& Tichenor, P. J. (1989). Structure and constraints on community newspaper gatekeepers. Journalism Quarterly, 66, 807-812, 845.

Dudley, R. L., \& Gitelson, A. R. (2002). Political literacy, civic education, and civic engagement: A return to political socialization? Applied Developmental Science, 6, 175-182.

Dunwoody, S., \& Griffin, R. J. (1999). Structural pluralism and media accounts of risk. In D. Demers \& K. Viswanath (Eds.), Mass media, social control, and social change: A macrosocial perspective (pp. 139-158). Ames: Iowa State University Press.

Harry, J. C. (2001). Covering conflict: A structural-pluralist analysis of how a small-town and a big-city newspaper reported an environmental controversy. Journalism and Mass Communication Quarterly, 78, 419-436.

Hindman, D. B. (1996). Community newspapers, community structural pluralism, and local conflict with nonlocal groups. Journalism and Mass Communication Quarterly, 73, 708-721.

Hindman, D., \& Homstad, C. (2000, November). Community structural pluralism and newspaper adoption and use of information technologies. Paper presented at the annual conference of the Midwest Association for Public Opinion Research, Chicago, IL.

Hindman, D. B., Littlefield, R., Preston, A., \& Neumann, D. (1999). Structural pluralism, ethnic pluralism, and community newspapers. Journalism and Mass Communication Quarterly, 76, 250-263.

Hooghe, M. (1999). Participation and the formation of social capital: An exploration of the causal relation between participation and social attitude. Sociologische Gids, 46, 494-520.

Janowitz, M. (1952). The community press in an urban setting: The social elements of urbanism. Chicago: University of Chicago Press.

Jeffres, L. W., Bracken, C., Jian, G., \& Casey, M. (2009). The impact of third places on community quality of life. Applied Research in Quality of Life, 13, 333-345.

Jeffres, L. W., Cutietta, C., Sekerka, L., \& Lee, J. (2000). Newspapers, pluralism and diversity in an urban context. Mass Communication \& Society, 3, 157-184.

Jeffres, L. W., Neuendorf, K. A., Bracken, C. C., \& Atkin, D. (2008). Impact of cosmopoliteness and communication on people's quality of life perceptions. The Open Communication Journal, 2, 17-22.

Kasarda, J., \& Janowitz, M. (1974). Community attachment in mass society. American Sociological Review, 39, 328-339.

Mackun, P. J. (2005, September). Population change in metropolitan and micropolitan statistical areas 1990-2003. Current Population Reports.

Marsden, P. V. (2005). The sociology of James S. Coleman. Annual Review of Sociology, 31, $1-24$.

Mayer, N. (2003). The political consequences of "social capital": The case of France. Revue Internationale de Politique Comparee, 10, 381-395.

Milbrath, L. W. (1965). Political participation: How and why do people get involved in politics? Chicago: Rand McNally.

Olien, C. N., Donohue, G. A., \& Tichenor, P. J. (1978). Community structure and media use. Journalism Quarterly, 55, 445-455. 
Olien, C. N., Tichenor, P. J., Donohue, G. A., Sandstrom, K. L., \& McLeod, D. M. (1990). Community structure and editor opinions about planning. Journalism Quarterly, 67, 119-127.

Pollock, J. (2007). Tilted mirrors: Media alignment with political and social change-A community structure approach. Cresskill, NJ: Hampton.

Pollock, J. D., Piccillo, C., Leopardi, D., Gratale, S., \& Cabot, K. (2005). Nationwide newspaper coverage of Islam post-September 11: A community structure approach. Communication Research Reports, 22, 15-27.

Preacher, K. J., \& Leonardelli, G. J. (2003). Calculation for the Sobel test. Retrieved April 22, 2010, from http://www.people.ku.edu/ preacher/sobel/sobel.htm

Price, B. (2002). Social capital and factors affecting civic engagement as reported by leaders of voluntary associations. The Social Science Journal, 39, 119-127.

Putnam, R. D. (1995). Bowling alone: America's declining social capital. Journal of Democracy, 6, 65-78.

Rothenbuhler, E. W., Mullen, L. J., DeLaurell, R., \& Ryu, C. R. (1996). Communication, community attachment and involvement. Journalism \& Mass Communication Quarterly, 73, 445-466.

Scheufele, D. A., Nisbet, M. C., Brossard, D., \& Nisbet, E. C. (2004). Social structure and citizenship: Examining the impacts of social setting, network heterogeneity, and informational variables on political participation. Political Communication, 21, 315-338.

Stamm, K. R. (1985). Newspaper use and community ties: Toward a dynamic theory. Norwood, NJ: Ablex.

Stamm, K. R., Emig, A. G., \& Hesse, M. B. (1997). The contribution of local media to commmunity involvement. Journalism \& Mass Communication Quarterly, 74, 97-107.

Tichenor, P. J., Donohue, G. A., \& Olien, C. N. (1973). Mass communication research: Evolution of a structural model. Journalism Quarterly, 50, 419-425.

Tichenor, P. J., Donohue, G. A., \& Olien, C. N. (1980). Community conflict and the press. Beverly Hills, CA: Sage.

Toennies, F. (1957). Community and society (C. P. Loomis, Trans.). New York: Harper Torchbook. (Original work published 1887).

Viall, E. K. (1992). Measuring journalistic values: A cosmopolitan/community continuum. Journal of Mass Media Ethics, 7, 41-53.

Wilson, T. C. (1986). Community population size and social heterogeneity: An empirical test. American Journal of Sociology, 91, 1154-1169.

Wirth, L. (1938). Urbanism as a way of life. American Journal of Sociology, 44, 3-24. 


\section{APPENDIX}

TABLE A1

Breakdown of Population and Heterogeneity Measures by Type of Community

\begin{tabular}{|c|c|c|c|c|c|c|c|}
\hline & \multicolumn{7}{|c|}{ Heterogeneity measures } \\
\hline & $\begin{array}{l}\text { Overall } \\
\text { heterogeneity } \\
\text { scale }\end{array}$ & $\begin{array}{l}\text { Income } \\
\text { hetero- } \\
\text { geneity }\end{array}$ & $\begin{array}{l}\text { Education } \\
\text { hetero- } \\
\text { geneity }\end{array}$ & $\begin{array}{l}\text { Age } \\
\text { hetero- } \\
\text { geneity }\end{array}$ & $\begin{array}{l}\text { Racial-ethnic } \\
\text { hetero- } \\
\text { geneity }\end{array}$ & $\begin{array}{l}\text { Occupational } \\
\text { hetero- } \\
\text { geneity }\end{array}$ & $\begin{array}{l}\text { Marital } \\
\text { hetero- } \\
\text { geneity }\end{array}$ \\
\hline $\begin{array}{c}\text { Central city metro } \\
\text { neighborhood }^{a}\end{array}$ & 4.29 & .87 & .80 & .89 & .36 & .75 & .62 \\
\hline $\begin{array}{l}\text { Nearby suburb } \\
\text { in metro } \text { area }^{b}\end{array}$ & 4.10 & .86 & .79 & .89 & .25 & .72 & .58 \\
\hline $\begin{array}{l}\text { More distant } \\
\text { suburb in } \\
\text { metro area }{ }^{c}\end{array}$ & 4.09 & .86 & .78 & .89 & .25 & .73 & .57 \\
\hline $\begin{array}{l}\text { Fair-sized city } \\
\text { outside metro } \\
\text { area }^{d}\end{array}$ & 4.14 & .87 & .78 & .90 & .29 & .72 & .59 \\
\hline $\begin{array}{l}\text { Small town } \\
\text { outside metro } \\
\text { area }^{e}\end{array}$ & 4.08 & .86 & .78 & .90 & .19 & .77 & .58 \\
\hline \multirow[t]{5}{*}{ In the country ${ }^{f}$} & 4.04 & .86 & .76 & .90 & .17 & .77 & .57 \\
\hline & $F=5.7$ & $F=2.5$ & $F=5.1$ & $F=7.5$ & $F=7.5$ & $F=11.1$ & $F=5.9$ \\
\hline & $p<.001$ & $p<.04$ & $p<.001$ & $p<.001$ & $p<.001$ & $p<.001$ & $p<.001$ \\
\hline & & \multicolumn{6}{|c|}{ Census population } \\
\hline & & \multicolumn{2}{|c|}{ Community population } & \multicolumn{2}{|c|}{ County population } & \multicolumn{2}{|c|}{ Metro population } \\
\hline \multirow{8}{*}{\multicolumn{2}{|c|}{$\begin{array}{l}\text { Central city metro neighborhood } \\
\text { Nearby suburb in metro area } \\
\text { More distant suburb in metro area } \\
\text { Fair-sized city outside metro area } \\
\text { Small town outside metro area } \\
\text { In the country }\end{array}$}} & \multicolumn{2}{|c|}{$648,578.6$} & \multicolumn{2}{|r|}{$1,562,626.8$} & \multicolumn{2}{|c|}{$3,215,324.3$} \\
\hline & & \multicolumn{2}{|c|}{$226,051.1$} & \multicolumn{2}{|r|}{$1,135,729.2$} & \multicolumn{2}{|c|}{$2,324,091.3$} \\
\hline & & \multicolumn{2}{|c|}{$152,094.0$} & & $1,220,593.9$ & \multicolumn{2}{|c|}{1.940 .834 .4} \\
\hline & & \multicolumn{2}{|c|}{$183,279.8$} & & $1,036,118.0$ & \multicolumn{2}{|c|}{$\begin{array}{l}1,940,034.4 \\
1,676,364.6\end{array}$} \\
\hline & & \multicolumn{2}{|c|}{$42,274.8$} & & $414,143.7$ & \\
\hline & & \multicolumn{2}{|c|}{$18,248.6$} & & $145,929.3$ & \multirow{2}{*}{\multicolumn{2}{|c|}{$\begin{array}{c}517,598.6 \\
96,012.3 \\
00 \text { (half lived in metro } \\
\text { areas) }\end{array}$}} \\
\hline & & \multicolumn{2}{|c|}{$M d n=22,897$} & \multicolumn{2}{|c|}{$M d n=237,966.5$} & & \\
\hline & & $F=$ & $9, p<.001$ & & $=6.6, p<.001$ & \multicolumn{2}{|c|}{$F=13.0, p<.001$} \\
\hline $\begin{array}{l}{ }^{a} N=48 . \\
{ }^{b} N=76 . \\
{ }^{c} N=36 . \\
{ }^{d} N=31 . \\
{ }^{c} N=74 . \\
{ }^{c} N=67 .\end{array}$ & & & & & & & \\
\hline
\end{tabular}

Post-print standardized by MSL Academic Endeavors, the imprint of the Michael Schwartz Library at Cleveland State University, 2016 